\title{
Filantropi Islam dan Aktivitas Sosial Berbasis Masjid di Masjid Al-Hidayah Purwosari Yogyakarta
}

\author{
Muhammad Irham \\ UIN Sunan Kalijaga
}

Naskah diterima 12 Sept 2018, direvisi 1 Okt 2018, disetujui 5 Des 2018

\begin{abstract}
This study explained how Mosque as the community of Muslim are able to finance social activities and conduct the program of community empowerment through the practice of Islamic philanthropy. By taking a case in a village in Sleman Regency, Yogyakarta, at where getting a Mosque that had been oriented toward religious and social activities of the community, namely the Mosque of Al-Hidayah Purwosari Sinduadi Village, Mati District, which established since 1972 and has survived to the present. This research aimed to see how the Mosque's involvement in philanthropic activities led at the program of local community empowerment. This research is important in doing because of the mosque's ability to collect and manage the fund of philanthropic for social activities. The data of this study were obtained through step ny step doing interview, observation, documentation and religious literature relevant to this study. The result of this study indicated that the fund of philanthropic came from zakat, infaq, alms and endowments that have been collected are distributed in the program of community empowerment which covered four main fields namely da'wah, education, social and economy. Finally, this study concluded that Mosque of al-Hidayah Purwosari was not only oriented toward worship, but also led to the programs of sustainable community empowerment through the practice of Islamic philanthropy.
\end{abstract}

Keywords: Islamic Philanthropy, Sosial Activis, Mosque of al-Hidayah, Empowerment

Abstrak Penelitian ini mendiskusikan bagaimana masjid sebagai komunitas Muslim mampu membiayai aktivitas-aktivitas sosial dan melakukan program pemberdayaan masyarakat melalui praktik filantropi Islam. Dengan mengambil kasus di sebuah desa di wilayah Kabupaten Sleman, Yogyakarta, dimana terdapat sebuah masjid yang berorientasi pada aktivitas keagamaan dan sosial masyarakat yakni Masjid alHidayah Purwosari, Desa Sinduadi Kecamatan Mati, yang berdiri sejak tahun 1972 dan bertahan hingga saat ini. Penelitian ini bertujuan untuk melihat bagaimana keterlibatan masjid dalam aktivitas filantropi yang diarahkan dalam program pemberdayaan masyarakat setempat. Penelitian ini penting karena kemampuan masjid dalam 
mengumpulkan dan mengelola dana filantropi untuk aktivitasaktivitas sosial kemasyarakatan. Data penelitian ini diperoleh melalui wawancara, observasi dan dokumentasi. Hasil penelitian ini menunjukkan bahwa dana filantropi yang bersumber dari zakat, infaq, sedekah dan wakaf yang telah dikumpulkan didistribusikan pada program-program pemberdayaan masyarakat yang meliputi empat bidang utama yakni dakwah, pendidikan, sosial dan ekonomi. Akhirnya, penelitian ini berkesimpulan bahwa Masjid al-Hidayah Purwosaritidak hanya berorientasi pada pelaksanaan ibadah semata, tetapi juga mengarah pada program-program pemberdayaan masyarakat secara berkelanjutan melalui praktik filantropi Islam.

Kata kunci: Filantropi Islam, Aktivis Sosial, Masjid al-Hidayah, Pemberdayaan

\section{A. PENDAHULUAN}

Penelitian ini mengkaji praktik filantropi Islam berbasis masjid yang diinisiasi oleh praktik filantropi Islam melalui dua institusi, yakni masjid dan pesantren sebagai komunitas Muslim sejak awal kedatangan Islam di Indonesia. Secara spesifik, studi ini berusaha mengkaji Masjid alHidayah Purwosari, Desa Sinduadi, Kecamatan Mlati, Kbaupaten Sleman, Provinsi Yogyakarta yang dilihat sebagai aktor non negara dalam mendistribusikan kesejahteraan. Menurut Minako Sakai, aktor non negara ini berperan membantu pemerintah dalam memberikan bantuan kepada mereka yang membutuhkan dan berperan melaksanakan program-program sosial dalam rangka meningkatkan kesejahteraan yang belum tersentuh oleh pemerintah (negara), dengan kata lain mengisi kekosongan negara (Sakai, 2012:373; Palahuddin, 2018). Studi ini menunjukkan bahwa Masjid al-Hidayah Purwosari telah berperan sebagai komunitas Muslim dalam mengisi kekosongan negara dalam mendistribusikan kesejahteraan melalui program-program karitas dan progam-program pemberdayaan yang sebagian besar belum tersentuh oleh perhatian negara terutama yang diperuntukkan kepada masyarakat Purwosari dan sekitarnya. Peneliti berpendapat bahwa praktik filantropi berbasis masjid yang diinisiasi oleh Masjid al-Hidayah Purwosari ini merupakan bagian dari perkembangan praktik filantropi di lingkungan masjid yang mengarah pada aktivitas sosial dan pemberdayaan masyarakat.

Tulisan ini berkontribusi pada kajian mengenai masjid dan praktik filantropi Islam. Dalam diskusi akademik, setidaknya terdapat dua 
kecenderungan yang menjadi bahasan umum terhadap dua hal tersebut, yakni pertama, melihat bagaimana kontribusi kegiatan filantropi dalam memperkuat masjid merealisasikan kegiatan-kegiatannya, dan kedua, bagaimana peran masjid dalam menguatkan aktivisme filantropi.

Studi-studi mengenai filantropi Islam dan aktivisme sosial di Indonesia menunjukkan bahwa filantropi Islam telah dipraktikkan oleh berbagai komunitas Muslim baik itu masjid, pesantren, yayasan, maupun lembaga filantropi dengan berbagai program-program kreatif yang ditawarkan dalam tujuan meningkatkan kesejahteraan masyarakat. Hilman Latief misalnya, dalam tulisannya mengenai "Filantropi Islam dan Aktivisme Sosial Berbasis Pesantren di Pedesaan" menunjukkan bahwa pesantren sebagai komunitas Muslim berperan dalam mendistribusikan kesejahteraan melaui aktivitas-aktivitas sosial kemasyarakatan. Latief dalam tulisannya ini menjelaskana kemampuan pesantren yang berlokasi di pedesaan, yakni Pesantren Darul Ulum Pedukuhan Sewugalur, Kabupaten Kulon Progo, Provinsi Yogyakarta dalam mengelola dana filantopi yang diarahkan pada pembinaan masyarakat melaui aktivitas dakwah dan sosial kemasyarakatan (Latief, 2012).

Melanjutkan studi yang sudah ada, penelitian ini akan menelusuri praktik filantropi Islam dan aktivisme sosial berbasis masjid. Penelitian ini penting disebabkan karena studi mengenai hal ini belum banyak dilakukan dalam diskusi akademik. Disamping itu, penulis juga melihat peranan masjid saat ini yang tidak hanya berperan sebagai tempat ibadah, tetapi juga berperan sebagai pilar kekuatan sosial dan ekonomi umat. Berbeda dengan temuan sebelumnya, penelitian ini menelusuri praktik filantropi yang diinisisai oleh masjid dan menyoroti programprogram pemberdayaan masyarakat yang dilaksanakan melalui pemanfaatan dana filantropi baik zakat, infaq, sedekah dan wakaf.

Penelitian ini memfokuskan kajian pada praktik filantropi Islam dan program pemberdayaan masyarakat di Masjid al-Hidayah Purwosari yang merupakan salah satu contoh masjid dengan manajemen modern yang telah mempraktikkan aktivitas sosial dan program-program pemberdayaan masyarakat melalui dana filantropi Islam. Masjid alHidayah Purwosari merupakan sebuah masjid yang berorientasi pada aktivitas keagamaan dan sosial masyarakat sejak pendiriannya pada tahun 1972 M hingga saat ini. Lebih menariknya, masjid ini telah melaksanakan program-program pemberdayaan masyarakat dengan 
merevitalisasi skema filantropi Islam. Hal tersebut menjadi daya tarik bagi penulis untuk mengkaji lebih lanjut dalam sebuah penelitian ilmiah.

Penelitian ini berupaya menyoroti lebih lanjut mengenai bagaimana praktik filantropi Islam yang diinisiasi oleh Masjid al-Hidayah Purwosari dan bagaimana program-program pemberdayaan masyarakat yang dilakukan, sehingga penelitian ini diharapkan dapat berkontribusi pada kajian filantropi Islam dan pemberdayaan masyarakat yang dipelopori oleh komunitas Muslim sebagai aktor non negara dalam mengisi hal-hal yang belum tersentuh oleh negera atau pemerintah melalui programprogram kreatif secara berkelanjutan.

\section{B. METODE PENELITIAN}

Jenis penelitian ini adalah penelitian lapangan dengan menggunakan pendekatan kualitatif. Studi kasus dalam penelitian ini adalah Masjid alHidayah Purwosari, Desa Sinduadi, Kecamatan Mati, Kabupaten Sleman, Provinsi Yogyakarta. Data penelitian ini diperoleh dari observasi langsung, wawancara dan dokumentasi. Informan dalam penelitian ini berjumlah 7 orang. 3 orang dari pengurus masjid sebagai informan kunci, 2 orang dari anggota takmir masjid serta 2 orang dari jamaah tetap Masjid al-Hidayah Purwosari sebagai informan pendukung. Data yang diperoleh dianalisis dengan menggunakan analisis kualitatif deskriptif yakni dengan cara memaparkan informasi-informasi aktual yang diperoleh terutama terkait praktik filantropi Islam dan programprogram pemberdayaan masyarakat berbasis masjid secara sistematis.

\section{HASIL DAN PEMBAHASAN}

\section{Masjid al-Hidayah Purwosari: Pengabdian dan Pembiayaan}

Masjid al-Hidayah Purwosari merupakan salah satu masjid dengan manajemen modern yang berorientasi pada aktivitas-aktivitas

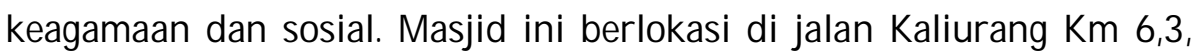
tepatnya di Pedukuhan Purwosari, Desa Sinduadi, Kecamatan Mlati, Kabupaten Sleman, Daerah Istimewa Yogyakarta. Masjid yang didirikan pada tahun 1972 ini berdiri di atas tanah seluas $500 \mathrm{~m}^{2}$ yang awalnya berasal dari tanah wakaf dari keluarga Bapak Marto Sentono.

Pengembangan dan pembangunan Masjid al-Hidayah Purwosari menjadi sebuah masjid yang dijadikan sebagai pusat keagamaan dan kegiatan sosial kemasyarakatan dilatarbelakangi oleh perkembangan masyarakat dan komunitas secara pesat dan semakin padat di daerah 
jalan Kaliurang tepatnya pada tahun 2005, sehingga berdampak pula pada perkembangan penduduk Muslim yang semakin bertambah khususnya di kawasan Pedukuhan Purwosari. Hal ini menyebabkan bangunan masjid yang kecil dan sederhana pada awal pendiriannya tidak lagi mampu menampung banyak jamaah. Kapasitas masjid yang hanya mampu menampung sekitar 300 jamaah sering kali mengakibatkan pelaksanaan ibadah menjadi kurang khusuk dan nyaman akibat jamaah yang melimpah sampai ke halaman masjid dan halaman rumah di sekitar masjid.

Berdasarkan fenomena tersebut, maka pengurus masjid dan masyarakat Purwosari menginginkan adanya pengembangan bangunan masjid untuk diperluas sebagai pusat peribadatan dan sosial kemasyarakatan. Pengembangan bangunan ini dimulai dengan membeli tanah kosong disekitar masjid sebagai lahan baru untuk perluasan pembangunan masjid yang dananya berasal dari warga dan para donatur. Dalam proses pengembangan bangunan masjid ini, pengurus bekerjasama dengan Yayasan Roudhotul Hidayah dengan membentuk panitia pembangunan pengembangan Masjid al-Hidayah yang bertugas mulai dari perencanaan, penataan kawasan dan bangunan masjid hingga yang bertugas sebagai aktor untuk mendapatkan segala dukungan dari berbagai pihak sampai terwujudnya bangunan dan kawasan Masjid alHidayah sesuai dengan tuntutan umat (Dokumentasi Masjid al-Hidayah Purwosari).

Menurut hemat penulis, proses pembangunan dan pengembangan Masjid al-Hidayah Purwosari melibatkan peran masyarakat Muslim khususnya di kawasan Purwosari dan sekitarnya yang dilatarbelakangi oleh harapan tersedianya bangunan dan fasilitas yang memadai sehingga dapat menjadi pusat pembinaan umat ke arah yang lebih baik. Hal ini sejalan dengan konsep pendirian masjid dalam konteks sejarah Indonesia. Sebagaimana Fauziah (2016) menyebutkan bahwa peran masyarakat Muslim yang secara sukarela mendirikan masjid di desa mereka adalah satu hal yang tidak kalah penting dalam proses pendirian dan pengembangan masjid sebagai pusat ibadah dan sosial masyarakat. Fauziah menegaskan bahwa mayoritas masjid yang terdapat di komunitas Muslim biasanya didirikan oleh warga desa itu sendiri melalui wakaf, sumbangan komunal dan tenaga sukarelawan yang tradisi ini bertahan hingga sekarang. 
Masjid yang didirikan atas swadaya masyarakat ini, tentu memiliki tanggung jawab sosial bagi masyarakat setempat. Oleh karena itu, para pendiri dan pengurus Masjid al-Hidayah Purwosari sampai sekarang, bercita-cita menjadikan Masjid al-Hidayah Purwosari sebagai pusat pembinaan umat, yang tidak hanya berorientasi pada ibadah saja, tetapi berorientasi pada pemberdayaan dan pengembangan masyarakat.

"Pemberdayaan dan pengembangan masyarakat melalui kegiatankegiatan sosial kemasyarakatan yang meliputi berbagai bidang, adalah tujuan utama didirikan dan dibangunnya Masjid al-Hidayah Purwosari ini. Menjadikan masjid sebagai pusat kegiatan apapun yang mengarah pada pengembangan masyarakat. Karena ketaatan beribadah kami sebagai pengurus tidak berarti apa-apa, jika kami tidak memperhatikan masyarakat sekitar dan tidak memberdayakan mereka. Ini adalah bentuk pengabdian kami kepada masyarakat, dan memberikan keyakinan kepada mereka bahwa masjid adalah solusi atau tempat atas setiap perkara." (HT, wawancara, 24 Oktober 2018).

Mengelola sebuah masjid, diperlukan kesungguhan dan profesionalisasi yang diselaraskan dengan fungsi masjid yang telah ditetapkan. Untuk mendukung aktivitas masjid dalam mewujudkan fungsi dan tujuannya, diperlukan ketersediaan dana yang cukup memadai. Sebab dana merupakan salah satu faktor utama sebagai pendukung terselenggaranya kegiatan-kegiatan masjid. Oleh karena itu, setiap masjid melalui pengurusnya berupaya untuk mengumpulkan dana dari berbagai sumber. Sumber pendanaan masjid dapat berasal dari donatur tetap dan tidak tetap, kotak amal, zakat, infaq dan sedakah, sumbangan pemerintah, sumbangan instansi swasta dan lain sebagainya. Dana yang terkumpul dari berbagai sumber tersebut digunakan untuk kegiatan-kegiatan masjid baik yang bersifat internal masjid maupun kegiatan eksternal masjid (Supardi dan Amiruddin, 2001: 33).

Masjid al-Hidayah Purwosari, sebagai pusat keagamaan dan sosial masyarakat Purwosari dan sekitarnya, juga memerlukan dana dalam melaksanakan setiap program yang telah ditetapkan. Pembiayaan dari pelaksanaan program-program kegiatan di Masjid al-Hidayah Purwosari berasal dari tiga sumber yang meliputi (a) dana dari donatur tetap dan non tetap yang diperoleh melalui pengajuan proposal permohonan dana baik individu maupun instansi swasta, (b) dana dari zakat terutama 
zakat maal (harta) yang diperoleh dari jamaah, (c) dana infaq dan sedekah yang diperoleh dari kotak infaq atau diberikan secara langsung oleh jamaah kepada pengurus masjid. Dana-dana yang terkumpul dari sumber tersebut digunakan untuk membiayai segala keperluan masjid dan mendanai segala bentuk program kegiatan masjid terutama diarahkan pada pengembangan masyarakat dalam rangka memberdayakan mereka dalam berbagai bidang seperti dakwah, pendidikan, sosial dan ekonomi (HT, wawancara, 24 Oktober 2018).

Berdasarkan penjabaran di atas, dapat dipahami bahwa Masjid alHidayah Purwosari merealisasikan tanggung jawab sosialnya melalui aktivitas-aktivitas yang mengarah pada pengembangan masyarakat yang dipelopori oleh pengurus masjid dan bekerjasama dengan semua komponen atau lapisan masyarakat sebagai bentuk pengabdian, dengan pembiayaan program kegiatan berasal dari berbagi sumber yang dapat menunjang terselenggaranya kegiatan yang dilaksanakan dalam mencapai tujuan yang diinginkan.

\section{Filantropi Islam, Aktivitas Sosial dan Program Pemberdayan Masyarakat}

Sub bahasan ini akan menelusuri bagaimana praktik filantropi Islam di Masjid al-Hidayah Purwosari, dan menyoroti program-program pemberdayaan masyarakat yang telah dilaksanakan sebagai bentuk keterlibatan masjid dalam mengelola dana filantropi untuk kesejahteraan masyarakat.Filantropi secara sederhana dapat diartikan sebagai bentuk kedermawanan melalui kegiatan memberi (Latief, 2013: 12). Secara umum filantropi dapat diartikan sebagai keinginan manusia untuk membantu orang lain melalui kegiatan memberi dan tindakan amal perbuatan lainnya yang dilandasi rasa cinta dengan tujuan menebarkan kebaikan untuk kepentingan publik (Fuadi, 2012:96). Dalam Islam, konsep filantropi dikenal dalam istilah zakat, infaq, sedekah (ZIS) dan wakaf. Istilah-istilah tersebut merujuk pada tindakan berderma yang mengandung makna kemurahan hati, keadilan sosial, saling berbagi dan saling memperkuat antar sesama manusia. Dengan demikian aktivitas berderma melalui zakat, infaq, sedekah dan wakaf inilah yang disebut dengan filantropi Islam. Tujuan dari filantropi Islam ini adalah tersalurnya harta kekayaaan dari orang-orang kaya kepada orang-orang miskin (Bamualim dan Abubakar, 2005: 6). 
Menurut Fuadi (2012) membagi praktik filantropi Islam menjadi dua bentuk, yakni filantropi tradisonal dan filantropi keadilan sosial. Filantropi tradisional merupakan bentuk praktik filantropi yang diaplikasikan dalam kegiatan karitas berupa pelayanan langsung yang bersifat jangka pendek dan lebih bersifat konsumtif seperti pemberian makanan, pakaian, tempat tinggal, pelayanan kesehatan dan sebagainya dengan tujuan memenuhi kebutuhan langsung dan kebutuhan dasar para penerima.Bentuk filantropi ini biasanya dilakukan oleh individu. Sementara filantropi keadilan sosial merupakan bentuk filantropi yang bertujuan meningkatkan kualitas hidup para penerima atau masyarakat terutama kaum miskin melalui program pemberdayaan secara berkelanjutan. Dengan kata lain, bentuk filantropi ini lebih bersifat produktif dan jangka panjang dengan tujuan akhir terciptanya keseteraan dan kesejahteraan sosial di tengah masyarakat. Praktik filantropi ini biasanya bersifat kolektif atau dipelopori oleh lembaga dan komunitas tertentu (Fuadi, 2012: 96-97). Filantropi keadilan sosial ini juga disebut dengan praktik filantropi modern (Latief, 2017: 33). Dengan demikian, dapat dipahami bahwa filantropi tradisional direalisasikan dalam bentuk layanan, sedangkan filantropi keadilan sosial atau modern dipraktikkan dalam bentuk advokasi berupa pemberdayaan masyarakat ke arah yang lebih baik.

Masjid al-Hidayah Purwosari yang menjadikan pengembangan dan pemberdayaan masyarakat sebagai tujuan atau orientasi utama dari keberadaan masjid ini, telah mempraktikkan aktivitas filantropi dalam rangka memberikan pelayanan kepada masyarakat setempat. Bentuk filantropi yang telah dipraktikkan juga meliputi bentuk filantropi tradisional dan filantopi modern. Filantropi tradisional, direalisasikan dalam bentuk pelayanan berupa santunan langsung. Sementara bentuk filantropi modern diarahkan dalam aktivitas-aktivitas sosial untuk pengembangan dan pemberdayaan masyarakat dalam berbagai bidang. Sub ini akan membahas bagaimana praktik filantropi Islam baik dalam bentuk tradisonal maupun modern di Masjid al-Hidayah Purwosari.

Praktik Filantropi Tradisional

Praktik filantropi tradisonal di Masjid al-Hidayah Purwosari ini direalisasikan dalam bentuk santunan langsung dengan tujuan memenuhi kebutuhan masyarakat, baik dalam bentuk makanan, uang, transportasi, tempat tinggal, pelayanan kesehatan dan lain sebagainya. 
Masjid al-Hidayah Purwosari menyediakan makanan siang setiap hari Jumat untuk semua jamaah yang melaksanakan shalat Jumat. Kegiatan ini adalah sebagai bentuk kedermawanan melalui kegiatan berbagi makanan dengan tujuan dapat memenuhi kebutuhan makan siang bagi jamaah yang melaksanakan shalat Jumat di Majid al-Hidayah Purwosari dan juga untuk memotivasi jamaah untuk senentiasa memakmurkan dan mengikuti program-program yang dilaksanaan masjid dalam upaya pengembangan masyarakat.

"Kami menyediakan sekitar 450 porsi makanan siang untuk jamaah yang melaksanakan shalat Jumat di masjid ini setiap Jumatnya. Sumber dana dari kegiatan ini berasal dari infaq jamaah terutama perorangan. Kami berupaya mencari donatur yang bersedia menyanggupi biaya dari menu makanan Jumatan ini. Disamping itu, kami juga mengumpulkan infaq dari jamaah melalui kotak infaq. Kegiatan ini bertujuan agar infaq atau pemberian dari jamaah dikembalikan kepada jamaah dalam bentuk berbagi makanan sehingga dapat merangkul jamaah dan menimbulkan kepercayaam jamaah kepada kami selaku pengurus masjid (PJ, wawancara, 25 Oktober 2018).

Praktik filantropi tradisional lainnya, juga direalisasikan dalam bentuk pemberian santunan berupa uang tunai kepada masyarakat khususnya masyarakat miskin dalam rangka membantu meringankan beban mereka dalam memenuhi kebutuhan sehari-hari (HT, wawancara, 24 Oktober 2018). Disamping itu, yang tidak kalah menarik dari bentuk filantropi tradisonal ini adalah memberikan pelayanan semaksimal mungkin kepada seluruh masyarakat Purwosari dan sekitarnya tanpa terkecuali baik penduduk Muslim maupun non Muslim untuk menggunakan fasilitas masjid dalam memenuhi kebutuhannya.

"Kami membuka kesempatan kepada seluruh masyarakat tanpa terkecuali untuk memanfaatkan fasilitas masjid. Misalnya, Kami memiliki satu unit Ambulance, sebagai fasilitas masjid yang diperuntukkan untuk seluruh masyarakat Purwosari dan sekitarnya tanpa terkecuali. Masyarakat diberikan kesempatan untuk memanfaatkannya dalam memenuhi kebutuhan pribadinya atau keluarganya, baik digunakan untuk membawa orang sakit, orang 
meninggal, dan keperluan lainnya demi kemaslahatan masyarakat. Ini sebagai bukti bahwa Masjid al-Hidayah Purwosari membuka diri dan berupaya melayani umat" (HT, wawancara, 24 Oktober 2018).

Praktik filantropi tradisional selain berasal dari infaq, sedekah dan sumbangan dari para donatur, praktik kedermawanan ini juga dipelopori oleh individu pengurus itu sendiri. Di mana terdapat salah satu dari pengurus yang memberikan bantuan khususunya kepada takmir atau tenaga pengelola masjid yang merupakan mahasiswa di berbagai universitas di Yogyakarta dalam pemenuhan kebutuhan mereka sehari-hari dan menyanggupi segala kepentingan perkuliahan mereka termasuk biaya perkuliahan mereka.

\begin{abstract}
"Saat ini Masjid al-Hidayah Purwosari memiliki 10 orang takmir dari berbagai wilayah di Indonesia. Ada yang dari Lombok, Riau, Sulawesi dan lain sebagainya. Pengurus masjid ini, mengutamakan remajaremaja yang telah menyelesaikan studinya di SMA atau sederajat dan berasal dari keluarga kurang mampu. Selama disini, kami diberikan fasilitas tempat tinggal yang layak dan fasilitas-fasilitas lainnya untuk keperluan sehari-hari. Ini semua difasilitasi oleh masjid. Namun yang sangat penting dan menarik, disini kami para takmir, disediakan sepeda motor sebagai alat transportasi kami ke kampus, dan biaya perkuliahan kami pun di sanggupi oleh Bapak Heriyanto selaku sekretaris pengurus Masjid al-Hidayah Purwosari". Ini adalah bentuk bantuan pribadi bagi kami dalam memenuhi kebutuhan perkuliahan" (IH, wawancara, 25 Oktober 2018).
\end{abstract}

"Disamping biaya perkuliahan, segala kepentingan perkuliahan kami juga disanggupi oleh Bapak Heriyanto. Seperti misalnya, kegiatan studi banding yang memerlukan biaya, kami hanya melapor ke Bapak Heriyanto selaku orang tua kami di sini. Kemudian beliau memberikan kami uang sejumlah keperluan kami untuk dibayarkan ke pihak kampus. Ini adalah bentuk kedermawanan berupa santunan langsung yang sangat membantu kami dalam kepentingan perkuliahan kami" (AN, wawancara, 25 Oktober 2018)

Praktik filantropi tradisional dalam bentuk karitaslainnya terlihat dari adanya programpenyediaaan pelayanan kesehatan. Program ini pernah dilaksanakan pada tahun 2015 yang direalisasikan dalam kegiatan pengobatan gratis bagi seluruh masyarakat Purwosari dan sekitarnya. Dalam pelaksanaan kegiatan ini, Masjid al-Hidayah 
Purwosari bekerjasama dengan para dokter yang ada di sekitar Purwosari. Kegiatan ini bertujuan untuk memudahkan masyarakat mendapatkan pelayanan kesehatan secara gratis dan terciptanya masyarakat yang sehat secara jasmani sehingga mampu untuk beribadah dan mengikuti kegiatan masjid lainnya (PJ, wawancara, 25 Oktober 2018).

Berdasarkan penjabaran di atas, dapat dipahami bahwa praktik filantropi tradisional ikut mewarnai aktivitas-aktivitas keagamaan dan sosial Masjid al-Hidayah Purwosari, terutama dalam bentuk karitas yang direalisasikan dalam kegiatan santunan dan pelayanan langsung yang bersifat jangka pendek, baik yang dipelopori langsung oleh masjid melalui peran pengurus yang bersifat komunitas maupun yang dipelopori oleh personal dalam pelaksanaannya.

\section{Praktik Filantropi Modern}

Filantropi modern yang mengarah pada pemberdayaan masyarakat secara berkelanjutan juga telah dipraktikkan di Masjid al-Hidayah Purwosari. Bentuk filantropi ini direalisasikan dalam program pemberdayaan masyarakat yang meliputi berbagai bidang diantaranya dakwah, pendidikan, sosial dan ekonomi yang bertujuan untuk memberdayakan masyarakat dalam rangka terwujudnya kesejahteraan masyarakat. Praktik filantropi ini diwarnai dengan berbagai bentuk kegiatan yang tujuan akhirnya adalah terwujudnya keterampilan dan kemandirian umat dalam segala aspek kehidupan.

Pemberdayaan Masyarakat dalam Bidang Dakwah, Masjid tidak bisa dipisahkan dari kegiatan keagamaan terutama aktivitas dakwah, bahkan tidak sedikit masjid yang memberdayakan jamaahnya melalui program dakwah yang direalisasikan dalam berbagai kegiatan. Begitu juga dengan Masjid al-Hidayah Purwosari, memfokuskan pemberdayaan masyarakat dalam bidang keagamaan melalui aktivitas dakwah. Kegiatan ini bertujuan sebagai wadah belajar bagi masyarakat dalam rangka mendapatkan ilmu agama untuk bekal dalam menjalani kehidupan sehari-hari.

Pemberdayaan masyarakat dalam bidang keagamaan atau dakwah ini direalisasikan dalam berbagai bentuk program pengajian. Pertama, Kajian Rutin. Kajian ini dilaksanakan setiap malam setelah shalat Magrib menjelang shalat Isya. Sasaran dari kajian ini adalah seluruh jamaah Masjid al-Hidayah Purwosari dan sekitarnya baik laki-laki maupun 
perempuan. Materi yang diberikan adalah isi pokok ajaran Islam yang meliputi, ibadah, syariah, akhlak, sejarah, mu'amalah dan lain sebagainya yang disusun oleh takmir masjid, dengan menghadirkan da'ida'i profesional dari luar kawasan Purwosari (WT, wawancara, 24 Oktober 2018).

Kedua, Kajian Mingguan. Kegiatan ini direalisasikan dalam bentuk kegiataan pembinaan membaca al-Qur'an dengan baik dan benar. Nama kegiatan ini adalah "Diraasah". Kegiatan ini dilaksanakan setiap hari Kamis setelah shalat Isya. Sasarannya adalah seluruh jamaah terutama yang sudah lanjut usia. Biasanya banyak diikuti oleh jamaah perempuan. Pengajian ini bertujuan membekali jamaah dengan ilmu tajwid dalam membaca al-Qur'an. Selain itu, kajian mingguan ini juga direalisasikan dalam bentukpengajian "fiqih wanita" yang khusus membahas terkait ajaran Islam tentang wanita. Sasaran utamanya adalah jamaah perempuan. Kegiatan ini dilaksanakan setiap hari Sabtu setelah shalat Isya. Kegiatan ini adalah sebagai bentuk pemberdayaan jamaah perempuan melalui aktivitas dakwah. Disamping itu, kegiatan ini juga bertujuan memberdayakan para ustadz yang ada disekitar Masjid alHidayah Purwosari sebagai pemateri pada kegiatan ini.

Ketiga,Kajian Bulanan. Kajian ini dilaksanakan pada hari minggu setiap bulannya dan biasanya dilaksanakan di pagi hari. Materi dalam kajian ini berbeda dengan kajian sebelumnya, materi kajian bulanan ini lebih bersifat tematiksesuai dengan kebutuhan atau permintaan dari jamaah dengan menghadirkan da'i-dai dari luar kawasan Purwosari, biasanya dari Yayasan al-Madinah Yogyakarta. Disamping itu, kajian bulanan ini juga dilaksanakan dalam bentuk upaya memberikan pemahaman kepada masyarakat mengenai kematian dan hari akhir dalam kajian "Sabtu Subuh" yang khusus membahas Kitab Hari Akhir. Kegiatan ini dilaksanakan setiap hari Sabtu setelah Shalat Subuh tiap bulannya (WT, wawancara, 24 Oktober 2018).

Pemberdayaan masyarakat melalui aktivitas dakwah di Masjid alHidayah Purwosari tersebut membawa perubahan ke arah yang lebih baik terutama pada peningkatan jumlah jamaah dari sebelumnya. Dengan adanya berbagai kegiatan dakwah ini dapat mendorong masyarakat sekitar Purwosari untuk memakmurkan masjid, karena jamaah merasa diperhatikan dan diberdayakan terutama tersedianya wadah untuk mendapatkan berbagai ilmu agama sebagai bekal dalam beribadah kepada Allah dan bergaul sesama manusia. Sehingga dengan 
kegiatan rutinitas ini berdampak pada meningkatnya jumlah jamaah dari sebelumnya, bahkan masyarakat luar Purwosari juga ikut serta meramaikan masjid dan mengikuti pengajian ini (JD, wawancara, 25 Oktober 2018).

Semua jenis kajian dakwah di atas, merupakan bentuk upaya yang dilakukan oleh pengurus Masjid al-Hidayah Purwosari dalam memenuhi kebutuhan masyarakat terutama kebutuhan akan ilmu-ilmu agama. Kegiatan dakwah ini dilaksanakan terus-menerus dan berkelanjutan sebagai bentuk pemberdayaan masyarakat dalam bidang keagamaan dengan tujuan agar terciptanya masyarakat yang agamis dilingkungan Masjid al-Hidayah Purwosari.

Pemberdayaan Masyarakat dalam Bidang Pendidikan, Program pemberdayaanmasyarakat berbasis masjid yang menarik lainnya di Masjid al-Hidayah Purwosari ini adalah pemberdayaan dalam bidang pendidikan. Pemberdayaan ini direalisasikan dalam berbagai program kegiatan. Diantaranya: Pertama, Taman Pendidikan Al-Qur'an (TPA). TPA merupakan wadah bagi anak-anak dalam mempelajari ilmu alQur'an. Keberadaaan TPA ini sejalan dengan berdirinya Masjid alHidayah Purwosari. Di mana TPA ini sebagai program pembinaan awal yang dirancang oleh para pendiri Masjid al-Hidayah Purwosari. Keberadaan TPA Masjid al-Hidayah Purwosari adalah sebagai jawaban dari permasalahan pendidikan al-Qur'an bagi anak-anak di Pedukuhan Purwosari yang kurang diperhatikan sebelumnya. Dengan adanya TPA ini anak-anak dan remaja bisa belajar dan mendapatkan ilmu-ilmu baru terutama dalam membaca al-Qur'an. Sehingga pada saat ini anak-anak dan remaja yang menekuni kegiatan belajar di TPA ini telah mampu membaca al-Qur'an dengan baik (LN, wawancara, 25 Oktober 2018)

Pengurus dan tenaga pengajar TPA berupaya menjadikan TPA ini sebagai wadah dalam memberdayakan masyarakat terutama kalangan anak-anak dan remaja dalam bidang pendidikan khususnya pendidikan al-Qur'an. Materi yang diberikan di TPA ini bukan hanya mengenai tajwid dan cara baca al-Qur'an, namun juga materi-materi keislaman lainnya sebagai bentuk pembinaan bagi generasi muda ( $\mathrm{IH}$, wawancara, 25 Oktober 2018).

Kedua, Bimbingan Belajar Siswa. Selain TPA, pemberdayaan masyarakat dalam bidang pendidikan direalisasikan dalam program bimbingan belajar siswa yang diperuntukkan bagi siswa-siswa yang masih duduk di bangku SD, SMP dan SMA. Kegiatan ini juga dilakukan di 
masjid tanpa dipungut biaya.Kegitan ini sebagai wadah belajar bagi anak-anak dan remaja untuk mendapatkan pengetahuan umum dan juga bertujuan membekali para siswa dan siswi yang akan mengikuti Ujian Nasional, Ujian Sekolah dan sejenisnya baik di tingkat SD, SMP maupun SMA. Kegiatan bimbingan belajar ini pada akhirnya membantu para orang tua siswa dalam membiayai bimbingan belajar anak-anaknya yang biasanya mahal di lembaga-lembaga bimbingan belajar. Kegiatan ini juga menunjukkan bahwa masjid dapat dijadikan sebagai lembaga bimbingan belajar siswa (HT, wawancara, 24 Oktober 2018).

Ketiga, Bimbingan Belajar Keluarga. Kegiatan ini dilaksanakan sekali dalam dua minggu. Materi yang diberikan dalam kegiatan bimbingan belajar ini adalah terkait tentang keluarga atau rumah tangga dan bimbingan membaca al-Qur'an. Metode yang digunakan dalam bimbingan belajar ini adalah metode rumah ke rumah. Dengan kata lain, para ustadz khususnya yang menetap di lingkungan Masjid al-Hidayah Purwosari mendatangi rumah-rumah jamaah secara bergantian sesuai kesepakatan bersama (WT, wawancara, 24 Oktober 2018). Anggota dalam bimbingan belajar ini biasanya diiikuti oleh keluarga-keluarga disekitar Purwosari melalui undangan atau pemberitahuan dari tuan rumah, dan kebanyakan pesertanya adalah jamaah perempuan (LN, wawancara, 25 Oktober 2018).

Keempat, Pengembangan Keterampilan Masyarakat. Program ini adalah sebagai upaya memberdayakan masyarakat dengan mengembangkan keterampilan mereka melalui berbagai pelatihan atau kursus. Sasaran utama dari program ini adalah generasi muda yang putus sekolah dan remaja-remaja yang berasal dari keluarga kurang mampu. Dengan kata lain, program ini ditujukan kepada mereka yang tidak melanjutkan pendidikannya ke perguruan tinggi. Metode yang digunakan dalam program ini adalah calon peserta memilih tempat di mana mereka akan mengikuti kursus, baik itu kursus menjahit, otomotif, elektronik dan keterampilan lainnya, setelah itu melaporkan kepada pengurus. Semua biaya selama pelatihan dibiayai oleh masjid melalui dana dari donatur, zakat, infaq dan sedekah (HT, wawancara, 24 Oktober 2018). Program ini bertujuan untuk mengembangkan keterampilan masyarakat Purwosari dan berupaya memberdayakan mereka sehingga mereka memiliki keterampilan sesuai dengan bidang yang dipilihnya untuk bekal mereka dalam mendapatkan pekerjaan nantinya. Masjid melalui pengurusnya mempunyai tanggung jawab untuk mengawasi dan 
mengevaluasi kegiatan ini, agar sasaran dan tujuan yang direncakan tercapai dengan baik.

Pemberdayaan Masyarakat dalam Bidang Sosial, Masjid al-Hidayah Purwosari yang berorientasi pada kegiatan-kegiatan keagamaan dan sosial ini, menjadikan kegiatan-kegiatan yang bersifat sosial kemasyarakatan sebagai metode dalam memberdayakan masyarakat. Masjid al-Hidayah Purwosari telah melaksanakan berbagai program unggulan di bidang sosial ini sebagai bentuk praktik pemberdayaan masyarakat melalui dana filantropi. Namun, Program pemberdayaan masyarakat yang bersifat jangka panjang atau berkelanjutan yang termasuk ke dalam praktik filantropi modern hanya terdapat satu program unggulan,yaitu "Daerah Binaan". Masjid al-Hidayah Purwosari memilki daerah binaan di Kabupaten Gunungkidul khususnya di kecamatan Paliyan. Sasaran dari program ini adalah beberapa desa di kecamatan Paliyan yang penduduknya mayoritas Mu'allaf atau baru tersentuh nilai-nilai Islam. Program ini bertujuan menyebarkan ajaran Islam dan membina masyarakat pedesaan serta menanamkan nilai-nilai Islam pada mereka agar tetap komitmen dalam memeluk agama Islam. Program ini dipelopori oleh pengurus Masjid al-Hidayah Purwosri bekerjasama dengan jamaah dan seluruh lapisan masyarakat beserta para ustadz dalam pembinaan masyarakat di daerah binaan ini dengan mengunjungi daerah tersebut bersama-sama.

\begin{abstract}
"Awalnya kami mendatangi daerah binaan tersebut sekali dalam sebulan. Kami dibantu oleh jamaah Masjid al-Hidyah Purwosari dan para ustadz lainnya dari Yayasan Raudhotul Hidayah, memberikan materi terkait isi ajaran Islam kepada penduduk di daerah binaan, membina mereka dalam pelaksanaan Ibadah dan lain sebaginya, serta memberikan bantuan kepada mereka. Seiring perkembangan waktu, penduduk di daerah tersebut memeluk agama Islam yang sebelumnya mayoritas non Muslim, dan memahami ajaran Islam. Kegiatan ini terus berlanjut hingga sekarang. Namun saat ini, kami hanya mengunjunginya sekali dalam enam bulan untuk mengawasi dan mengevaluasi perkembangannya dan agar mereka tetap komitmen pada ajaran Islam" (WT, wawancara, 24 Oktober 2018).
\end{abstract}

Program pemberdayaan melalui daerah binaan ini merupakan program unggulan dalam bidang sosial. Hal ini adalah sebagai bukti bahwa Masjid al-Hidayah Purwosari tidak hanya berorientasi pada pembinaan masyarakat setempat, namun juga mengarah pada 
pemberdayaan masyarakat luas di luar Purwosari terutama daerah yang membutuhkan (Laina, wawancara, 25 Oktober 2018).

Pemberdayaan Masyarakat dalam Bidang Ekonomi, Pemberdayaan masyarakat dalam bidang ekonomi yang mengarah pada pemberdayaan jangka panjang dan berkelanjutan,masih sebagai wacana atau dalam perencanaan. Namun, pelaksanaan program yang mengarah pada kegiatan ekonomi dalam rangka meningkatkan kesejahteraan masyarakat telah dipraktikkan di Masjid al-Hidayah Purwosari. Kegiatan ekonomi tersebut direalisasikan dalam dua program unggulan.

Pertama, Peminjaman Uang untuk modal usaha. Masjid al-Hidayah Purwosari melalui dana filantropi yang tersedia baik dari donatur, zakat, infaq dan sedekah membuka kesempatan bagi jamaah dan masyarakat Purwosari untuk meminjam uang melalui pengurus. Program ini bertujuan untuk memudahkan masyarakat dalam memenuhi kebutuhannya terutama membantu masyarakat mendapatkan modal membuka suatu usaha. Peminjaman ini dalam bentuk peminjaman uang tunai tanpa riba. Artinya, masyarakat mengembalikan sejumlah uang yang dipinjamnya kepada pengurus sesuai dengan waktu yang telah ditetapkan. Program ini merupakan suatu upaya memberdayakan ekonomi masyarakat menjadi lebih baik, karena disamping diberi pinjaman modal usaha, program ini juga diawasi perkembangan dan pelaksanaannya dengan tujuan masyarakat benar-benar memanfaatkan pinjaman untuk membantu meningkatkan perekonomian mereka melalui usaha mandiri yang mereka bangun dari modal pinjaman. Program ini berkelanjutan hingga saat ini bahkan sudah bekerjasama dengan seluruh ketua Rukun Tetangga (RT) di Pedukuhan Purwosari ini untuk mendata warganya yang membutuhkan pinjaman dana untuk modal usaha (Heriyanto, wawancara, 24 Oktober 2018).

Kedua, Pasar Murah. Kegiatan ekonomi yang bertujuan untuk meningkatkankan kesejahteraan masyarakat terutama kaum miskin juga direalisasikan dalam kegiatan pasar murah. Kegiatan ini dilaksanakan di pekarangan Masjid al-Hidayah Purwosari dalam bentuk kegiatan jualbeli. Dalam pasar murah ini, panitia menyediakan berbagai jenis barang terutama bahan-bahan pokok, dan menawarkan kepada masyarakat dengan harga murah. Kegiatan ini adalah sebagai bentuk upaya masjid untuk membantu masyarakat mendapatkan bahan pokok sebagai kebutuhannya sehari-hari dengan harga lebih murah dibandingkan tokoh. Kegiatan ini membantu masyarakat khususnya kaum miskin dan 
berupaya meningkatkan kesejahteraan dan kesetaraan ekonomi di lingkungan masyarakat Purwosari. Program ini hanya pernah dilaksanakan satu kali, yakni pada tahun 2015 dan tidak berkelanjutan. Namun untuk ke depannya, pengurus Masjid al-Hidayah Purwosari merencanakan akan mendirikan tokoh di halaman masjid dengan tujuan menjadi distributor barang-barang pokok seperti beras, minyak, gula dan sebagainya, dengan harapan masyarakat dapat memperoleh barang kebutuhannya dengan mudah dan harga lebih murah sehingga membantu masyarakat terutama kaum miskin dalam memenuhi kebutuhannya sehari-hari. Dalam pencapaian tujuan tersebut, pengurus mengajukan proposal bantuan dana ke berbagai instansi swasta dan bekerjasama dengan berbagai pihak yang dapat menunjang terlaksananya tujuan tersebut (Heriyanto, wawancara, 24 Oktober 2018).

Penjabaran di atas, memberikan pemahaman bahwa adanya perubahan fungsi dana filantropi Islam terutama zakat sebagai sumber dana terbesar di Masjid al-Hidayah Purwosari, yang tidak hanya mengarah pada santunan jangka pendek, namun juga difungsikan untuk pemberdayaan yang berkelanjutan. Hal ini sejalan dengan pandangan Retsikas (2014) yang mengilustrasikan adanya perubahan pemahaman zakat sebagai instrumen filantropi Islam yang awalnya dipahami sebagai ibadah tahunan yang hanya berorientasi pada bantuan jangka pendek mengarah kepada bentuk pemberdayaan jangka panjang untuk mewujudkan keadilan dan kesejahteraan sosial. Retsikas berargumen bahwa zakat memiliki fungsi dimensi sosial dan memiliki hubungan dengan keadilan sosial dan ekonomi. Penataan kembali fungsi zakat dan pengelolaan dengan baik dan profesional adalah hal yang sangat diperlukan saat ini agar zakat mampu menjadi sumber pranata sosial dan ekonomi umat.

Masjid merupakan tempat strategis sebagai Unit Pelaksana Teknis (UPT) pembinaan umat, yang selama ini belum mendapatkan perhatian lebih serius. Masjid apabila dikelola dengan manajemen modern akan dapat memberikan nilai tambah bagi pembinaan umat. Bahkan masjid dapat dijadikan sebagai lembaga filantropi Islam berbasis komunitas yang profesional dalam mengumpulkan, mengelola dan mendistribusikan dana-dana filantropi yang diarahkan untuk pemberdayaan masyarakat (Siskel, dkk, tt: 196). 
Menurut hemat penulis, Masjid al-Hidayah Purwosari merupakan contoh masjid dengan manajemen modern. Hal ini dapat dilihat dari kemampuan masjid dalam mengelola berbagai kegiatan keagamaan dan aktivitas sosial melalui aktivitas filantropi. Dengan demikian, dapat dipahami bahwa Masjid al-Hidayah Purwosari telah terlibat dalam praktik filantropi Islam dan aktivisme sosial yang diarahkan pada pemberdayaan masyarakat ke arah yang lebih baik.

\section{Memberdayakan Masyarakat dan Problematikanya}

Pemberdayaan masyarakat adalah proses memberdayakan masyarakat dalam semua aspek kehidupan untuk meningkatkan kualitas hidup dan kehidupannya ke arah yang lebih baik. Tujuan dari pemberdayaan masyarakat itu sendiri adalah berupaya untuk menjadikan masyarakat yang tidak berdaya atau lemah baik dalam hal ekonomi, pengetahuan, potensi, tidak adanya kesempatan untuk berinspirasi dan sebagainya menjadi masyarakat yang berdaya yaitu mampu memahami diri dan potensinya (Yazid dan Soim, 2016: 88).

Hakikat dari pemberdayaan adalah bagaimana membuat masyarakat mampu membangun dirinya dan memperbaiki kehidupannya sendiri. Istilah mampu di sini mengandung makna: berdaya, paham, termotivasi, memiliki kesempatan, melihat dan memanfaatkan peluang, berenergi, mampu bekerjasama, mampu mengambil keputusan, berani mengambil risiko, mampu mencari dan menangkap informasi, serta mampu bertindak sesuai inisiatif (Anwas, 2014: 50). Mardikanto dan Soebiato (2013) menegaskan bahwa pemberdayaan masyarakat merupakan proses meningkatkan kemampuan dan sikap kemandirian masyarakat

Penulis menambahkan bahwa pemberdayaan masyarakat dapat diartikan sebagai upaya memenuhi kebutuhan yang diinginkan oleh individu, kelompok dan masyarakat luas agar mereka memiliki kemampuan dan keterampilan melalui berbagai program kegiatan yang terencana, baik dilakukan oleh individu maupun komunitas tertentu. Dalam pelaksanaannya, pemberdayaan memiliki makna dorongan atau motivasi, bimbingan atau pendampingan dalam meningkatkan kemampuan individu atau masyarakat untuk mampu mandiri. Upaya tersebut merupakan sebuah tahapan dari proses pemberdayaan dalam mengubah perilaku, mengubah kebiasaan lama menuju perilaku baru yang lebih baik dalam meningkatkan kualitas hidup dan kesejahteraannya. 
Program-program pemberdayaan masyarakat berbasis masjid yang diinisiasi oleh Masjid al-Hidayah Purwosari sebagaimana disebutkan di atas, merupakan salah satu upaya dalam memberdayakan masyarakat melalui program-program kreatif dan terencana yang dilakukan oleh komunitas Muslim berbasis masjid. Program pemberdayaan yang dilakukan, juga bertujuan untuk memberdayakan masyarakat khususnya masyarakat Purwosari dan sekitarnya dalam segala aspek, baik keagamaan, pendidikan, sosial maupun ekonomi serta bertujuan memberikan kesempatan yang sama kepada masyarakat dalam memenuhi kebutuhannya terutama mendapatkan ilmu pengetahuan, kesempatan memperoleh pelayanan dan kesempatan mengembangkan keterampilan, sehingga masyarakat mampu mandiri dan kesejahteraan dapat terwujud dengan baik. Hal ini sejalan dengan konsep pemberdayaan masyarakat itu sendiri, yakni terwujudnya masyarakat yang berdaya dan mandiri dalam segala aspek kehidupan melalui program terencana yang dilakukan oleh komunitas tertentu.

Bagi sebuah masjid, melakukan pemberdayaan masyarakat bukanlah perkara mudah. Apalagi bila masjid tersebut belum mendapatkan dukungan sepenuhnya dari pengurus masjid dan berbagai pihak serta kurangnya kesadaran masyarakat yang diberdayakan. Masjid al-Hidayah Purwosari pun mengalami hal serupa, belum mendapatkan dukungan sepenuhnya dari pengurus masjid terhadap program pemberdayaan yang dilakukan. Hal ini ditandai dengan sulitnya waktu untuk bermusyawarah antar pengurus, dan hanya sebagian pengurus yang ikut secara langsung dalam proses kegiatan pemberdayaan masyarakat berbasis masjid dengan merevitalisasi skema filantropi Islam sebagaimana disebutkan di atas. Begitu juga dengan kesadaran masyarakat, masih terdapat masyarakat yang belum memahami tujuan dari program pemberdayaan yang dilakukan, sehingga mereka tidak mau mengikuti program pemberdayaan terutama dalam bidang dakwah dan pendidikan (HT, wawancara, 24 Oktober 2018).

Hambatan-hambatan tersebut, tidak berarti bahwa upaya memberdayakan masyarakat tidak berjalan sesuai dengan yang diharapkan. Faktanya, Masjid al-Hidayah Purwosari ini memiliki kiatkiat tersendiri dalam mengatasi problematika tersebut, sehingga program pemberdayaan masyarakat dapat dilakukan dengan baik dalam upaya mencapai tujuan yang ditetapkan. Masjid al-Hidayah Purwosari sebagaimana disebutkan sebelumnya, memberikan pelayanan sebaik- 
baiknya dan membuka kesempatan sebesar-besarnya kepada masyarakat untuk memanfaatkan fasilitas masjid dan berupaya memberdayakan mereka tanpa terkecuali serta menerima dan menghargai aspirasi masyarakat dan mengutamakan kebutuhan bersama di atas kepentingan individu, sehingga menjadi daya tarik tersendiri bagi masyarakat untuk mengikuti program yang dilaksanakan. Disamping itu, Masjid al-Hidayah Purwosari juga melakukan sosialisasi terhadap program pemberdayaan yang dilakukan untuk memberikan pemahaman kepada masyarakat, serta melakukan inovasi terhadap program sesuai kebutuhan masyarakat. Dan yang tidak kalah pentingnya, pengurus masjid juga melakukan strategi dalam mengajak segenap pengurus dan masyarakat untuk mengikuti setiap program pemberdayaaan, baik secara langsung atau tatap muka maupun melalui undangan, pemberitahuan dan sebagainya (HT, wawancara, 24 Oktober 2018).

Pemberdayaan masyarakat melalui berbagai program, hendaknya dilakukan secara terus-menerus atau berkelanjutan agar tujuan pemberdayaan yang ditetapkan dapat tercapai dengan baik. Begitu juga dengan program pemberdayaan masyarakat yang diinisisasi oleh Masjid al-Hidayah Purwosari melalui pemanfaatan dana filantropi sebagaimana disebutkan di atas, hendaknya terus dilakukan dan ditingkatkan secara berkelanjutan, sehingga tujuan untuk mewujudkan masyarakat Purwosari yang berdaya dan mandiri dalam berbagai aspek kehidupan dapat tercapai dengan baik.

\section{KESIMPULAN}

Praktik filantropi Islam di Masjid al-Hidayah Purwosari menunjukkan keterlibatan masjid dalam pembinaan dan pemberdayaan masyarakat melalui aktivitas-aktivitas sosial yang memanfaatkan dana filantopi Islam baik dari zakat, infaq, sedekah maupun wakaf. Aktivitas-aktivitas sosial tersebut adalah sebagai tanggung jawab sosial masjid sebagai pusat keagamaan dan sosial kemasyarakatan. Ini menunjukkan bahwa Masjid al-Hidayah Purwosari saat ini tidak hanya berorientasi pada ibadah semata, namun juga mengarah kepada program-program sosial dan pemberdayaan masyarakat secara berkelanjutan dalam upaya meningkatkan kesejahteraan masyarakat melalui praktik filantropi Islam. Praktik filantropi berbasis Masjid ini sebaiknya terus dilaksanakan dan diawasi agar fungsi masjid sebagai pusat keagamaan, 
sosial kemasyarakatan dan wadah pembinaan umat dapat terwujud dengan baik. Praktik filantropi berbasisis masjid seharusnya tidak hanya berorientasi pada bentuk pemberian suka rela yang bersifat jangka pendek, tetapi lebih mengarah pada upaya pemberdayaan masyarakat sehingga dapat membawa perubahan sosial sebagaimana dikehendaki oleh praktik filantropi Islam itu sendiri yakni terwujudnya masyarakat yang berdaya, baik di bidang dakwah, pendidikan, sosial dan ekonomi. Dengan tujuan akhir terciptanya kesetaraan dan kesejahteraan ditengah masyarakat, khususnya masyarakat di lingkungan masjid itu sendiri.

\section{DAFTAR PUSTAKA}

Anwas, M. O. 2014. Pemberdayaan Masyarakat di Era Global.Bandung: Alfabeta.

Bamualim, S. C\& I. Abubakar. 2005. Revitalisasi Filantropi Islam: Studi Kasus Lembaga Zakat dan Wakaf di Indonesia. Jakarta: Pusat Bahasa dan Budaya UIN Syarif Hidayatullah.

Dokumentasi Masjid al-Hidayah Purwosari, Sinduadi, Mati, Sleman, D.I Yogayakarta

Fauziah, A. 2016. Filantropi Islam : Sejarah dan Kontesasi Masyarakat

Sipil dan Negara di Indonesia,terj. Eva Mushoffa. Yogyakarta: Gading Publishing.

Fuadi,A. (2012)Towards the Discourse of Islamic Philanthropy for Social Justice in Indonesia.Jurnal Afkaruna, 8 (2), 92-102.

Latief, H. 2017. Melayani Umat: Filantropi Islam dan Ideologi Kesejahteraan KaumModernis. Yogyakarta: Suara Muhammadiyah.

. 2013. Politik Filantropi Islam di Indonesia: Negara, Pasar dan Masyarakat.Yogyakarta: Penerbit Ombak.

. (2012). Filantropi Islam dan Aktivisme Sosial Berbasis

Pesantren di Pedesaan. Jurnal Afkaruna, 8 (2), 167-187.

Mardikanto, T\& P. Soebiato. 2013. Pemberdayaan Masyarakat: Dalam Perspektif Kebiajkan Publik. Bandung: Alfabeta.

Palahuddin, P. (2018). Modernisasi Pendidikan Islam di Indonesia Awal Abad Ke-XX: Kasus Muhammadiyah. SANGKéP: Jurnal Kajian Sosial Keagamaan, 1(1), 61-83. 
Retsikas. K. (2014). Reconseptualising Zakat in Indonesia: Worship, Philanthropy and Right. Indonesia and the Malay World, 42 (124), 337-357

Sakai, M. (2012). Building a partnership for social service delivery in Indonesia: State and Fait-Based Organisation. Australian Journal of Social Issues, 47 (3), 373-388.

Siskel, E. S,dkk (The Ford Foundation). tt. Berderma untuk Semua: Wacana dan Praktik FilantropiIslam. Jakarta: Pusat Bahasa dan Budaya UIN Syarif Hidayatullah.

Supardi \& T. Amiruddin.2001. Manajemen Masjid dalam Pembangunan Masyakat: Optimalisasi Peran dan Fungsi Masjid. Yogyakarta: UII Press.

Yazid, Y\& M. Soim.2016. Dakwah dan Pengembangan Masyarakat. Jakarta: Rajawali Pers.

\section{Daftar Wawancara}

Wawancara dengan Bapak Heriyanto, selaku Sekretaris Pengurus Masjid al-Hidayah Purwosari, tanggal 24 Oktober 2018

Wawancara dengan Bapak Wartono, selaku Pengurus dan Ketua Bidang Keagaman Masjid al-Hidayah Purwosari, tanggal 24 Oktober 2018

Wawancara dengan Bapak Puji, selaku Pengurus dan Koordinator Menu Jum'atan Masjid al-Hidayah Purwosari, tanggal 25 Oktober 2018

Wawancara dengan Ihsan, selaku Anggota Takmir dan Kepala TPA Masjid al-Hidayah Purwosari, tanggal 25 Oktober 2018

Wawancara dengan Angga Aspan, selaku Anggota Takmir dan Bendahara Harian Masjid al-Hidayah Purwosari, tanggal 25 Oktober 2018

Wawancara dengan Bapak Junaidi, Selaku Jamaah Tetap Masjid alHidayah Purwosari, tanggal 25 Oktober 2018

Wawancara dengan Ibuk Idris Laina, Selaku Jamaah Tetap Masjid alHidayah Purwosari, tanggal 25 Oktober 2018 